\title{
Territory, Cluster and Competitiveness of the Intensive Horticulture in Almería (Spain)
}

\author{
José A. Aznar-Sánchez ${ }^{*}$ and Emilio Galdeano-Gómez
}

Department of Applied Economics, University of Almería, La Cañada de San Urbano-04120, Almería, Spain

\begin{abstract}
Almería is Spain's leading area for the production and exportation of vegetables. In this province we can find the largest area of greenhouses in the world, around which a major agroindustrial cluster has arisen. The present study follows a holistic approach to analyse its development and the modification of its sources of advantage. For this purpose, Porter's theoretical and analytical framework is considered. The particular natural resources of the territory were fundamental in the growth of this sector in the 1970's, allowing it to achieve absolute comparative advantages. Nowadays, the agroindustrial cluster that has built up around the greenhouse industry has enhanced the competitiveness of the sector by generating systemic and dynamic competitive advantages.
\end{abstract}

Keywords: Territory, agroindustrial cluster, competitiveness, intensive horticulture, Almería.

\section{INTRODUCTION}

The formation of a cluster in a given territory has a strong impact on the firms that make it up. In an international context in which it has become ever easier to uproot and change the location of productive processes, the emergence of a cluster constitutes an important factor for the competitiveness of a territory. In the industrial sector there is an abundance of studies and empirical analyses on the effects of the formation of clusters. However, as there has been little analysis of the agroindustrial sector, it is appropriate to study specific cases of clusters arising around agricultural activities which have enjoyed success based on the comparative advantages the territory has provided them with.

The present article studies the case of the cluster that has arisen around the intensive horticulture industry in Almería. The appearance and later evolution of greenhouse vegetable production in this province represents the greatest Spanish agrarian transformation of recent decades. From being considered a "desert", this province has evolved into the "market garden of Europe" [1]. The surface area dedicated to horticultural production has risen spectacularly over the last three decades to 27,000 hectares in 2009 , accounting for over half of the total greenhouse area in Spain. The highest concentration of plastic greenhouses in the world is to be found in this province in the so-called "Campo de Dalías" [2]. Over the same period the production has increased fourfold, from 669,218 tonnes in 1975 to $2,889,380$ tonnes in 2009, making this the Spanish region with the highest production of vegetables. Sales to overseas markets from the province have also rocketed, increasing from just over 80,000 tonnes in 1980 to over $1,630,000$ tonnes in 2009, making this the chief Spanish region for exports of vegetables [3].

*Address correspondence to this author at the Department of Applied Economics, University of Almería, 04120-Almería-España, Tel: 9500151 92; Fax: 9500154 72; E-mail: jaznar@ual.es
The social factor has played a major role in this model, as a high proportion of the farms are small, family-run concerns with a high capacity for creating employment. The 27,000 hectares of greenhouses are owned by some 13,500 farmers and give direct employment to over 40,000 workers annually (Table 1). As this activity is based fundamentally on small, family-run farms, the income generated by the sector has gone to quite a wide segment of the population of Almería.

Table 1. Basic Data on the Intensive Horticulture in Almería (Spain) 2009

\begin{tabular}{|c|c|}
\hline Setting up & End $1950 \mathrm{~s}$ \\
\hline Consolidation & Private initiative \\
\hline National Leadership & Mid 1980s \\
\hline Greenhouse-covered surface $(\mathrm{Ha})$ & 27.000 \\
\hline $\begin{array}{l}\% \text { out of national } \\
\text { greenhouse-covered surface }\end{array}$ & $52 \%$ \\
\hline Production (Tm) & 2.889 .380 \\
\hline$\%$ out of national production & $27 \%$ \\
\hline Exports $(\mathrm{Tm})$ & 1.630 .000 \\
\hline$\%$ out of national exports & $34 \%$ \\
\hline Enterprise number & 13.500 \\
\hline Average dimension $(\mathrm{Ha})$ & Great homogeneity $(2 \mathrm{Ha})$ \\
\hline Enterprise type & familiar \\
\hline Property regime & owners \\
\hline Workers & $\begin{array}{l}\text { Family members and employees } \\
(40.000)\end{array}$ \\
\hline Growers' Formation in agriculture & High \\
\hline
\end{tabular}

The economic model based on this intensive agriculture has allowed growth of both the economy and the population of Almería which is unprecedented in the recent history of Spain. The socioeconomic change that the sector has induced has been such that it has been described as a "miracle" [4-6]. 
Until the late 1960's Almería could have been classified as under-developed, and it was the penultimate Spanish province in terms of per capita GDP. Nevertheless, the appearance and subsequent development of intensive horticulture in the province led to levels of growth which surpassed regional and national averages, with the result that Almería is now the first province in Andalusia and it occupies an intermediate position on a national level. At the same time the province's population has grown considerably in recent years, making it the second province in terms of population growth and the first one in terms of immigration [7].

The present article studies the factors which gave rise to the growth and consolidation of intensive horticulture in Almería, placing special emphasis on the role played by the territory's particular natural resources. It also analyses the modification in the area's sources of advantage following a holistic and evolutionary approach.

The remainder of the article is structured as follows. The second section explains the analytical framework used to analyse the modification of the sources of advantage and the competitiveness of the horticultural sector in Almería. The third section goes on to analyse the natural, institutional, technological and social factors which influenced its growth. The fourth one describes the changes that took place in the fields of production, innovation, marketing and dimension which contributed to its consolidation. The basic features of the agro-industrial cluster which has grown up around the production of vegetables, gaining importance and diversification, are outlined in the fifth section. The sixth one analyses the competitiveness of the sector following Porter's theoretical model, while the seventh and final section draws the conclusions.

\section{ANALYTICAL FRAMEWORK}

The territorial question in the analysis of economic growth has hardly been dealt with in academic works, and it was not until recently that interest in studying spatial aspects of the economy started to grow. Nevertheless, unlike the neoclassic model in which space was understood fundamentally as distance, territory adopted a passive role. Space was only a source of costs of economic agents. However, new theoretical developments propose reconsidering the role of space in overall economic philosophy, stressing its active participation in processes of development, in such a way that the "space" variable becomes one of the ways to promote the generation of elements (external economies and growing profits) which mean that the model of imperfect competence is considered as the theoretical starting point.

Among the different approaches that have arisen we should highlight the theory of endogenous development. This considers development as a territorial process and its methodology is based on case studies. It considers that development policies are more efficient when carried out by local agents. This interpretation argues that spatial organization of production is one of the determining factors in processes of development, as is shown by the growing relevance of networks of businesses in the regions [8]. It takes economic growth to be an evolutionary process that is characterized by uncertainty and fate and is shaped by changes in market conditions and by the investment decisions of the agents. Firms take investment decisions bearing in mind their capabilities and the specific resources of the territory in which they are located, and so growth analysis is enriched by considering the territorial perspective. Moreover, economic progress does not depend only on the territory's resources and the saving and investment capacity of the economy, but also on the successful functioning of the mechanisms via which capital is accumulated (such as the organization of the systems of production, the diffusion of innovation, urban development of the territory and institutional changes), and on the interaction among these factors. All of these elements have contributed to making this interpretation facilitate the definition of strategies and policies which the agents of a given territory can carry out to take advantage of the opportunities that globalization brings $[9,10]$.

Given the profound transformation in the organization of production that took place from the 1970's on, with the loss of hegemony of the hierarchical models that were characteristic of the great Ford-type firm and the appearance of new, more flexible and decentralized forms, many theoretical interpretations started to appear. Among these were the interpretations of industrial districts [11], flexible specialization [12], new industrial spaces [13], industrial clusters [14], knowledge economy [15], new geographical economy [16, 17], innovative environment [18, 19], sociological [20] and institutionalist [21]. Therefore, there is no single interpretation on how production in a given territory is organized that enables us to explain the factors leading to the appearance of agglomerations and clusters of firms, or the mechanisms through which they develop, the reasons why they change and become transformed.

Of all these analytical approaches, we shall pay special attention to Porter's cluster [14, 22, 23], as it is the most appropriate for the aims of the present study since it focuses on competitiveness, seeking out the sources of competitive advantages for given places and sectors. Its common core with other approaches is the importance it attributes to the relationships between the agents and their geographical proximity and the conclusion that these give rise to economic advantages [24]. However, one of its most singular contributions is the profound development of the concept of competitiveness. It includes the cluster concept in its dynamic theory of competence, which highlights the systemic nature of the determining factors of competitiveness in its "diamond", which includes and interrelates factors of the macroeconomy, the sector and the firm. The four points of the diamond group together the four broad determining factors of competitiveness: composition and evolution of demand; conditions of the supply of factors; the strategy, structure and rivalry between firms in the markets; and the existence of connected and supporting sectors (Fig. 1). The effect of each of these tends to depend on the situation of the others and they also strengthen one another, constituting a system of mutual support. The diamond establishes the conditions for an advantage of superior order and it takes a great deal of time and effort to imitate it. Once it has been achieved, the cost of incorporation increases substantially. 


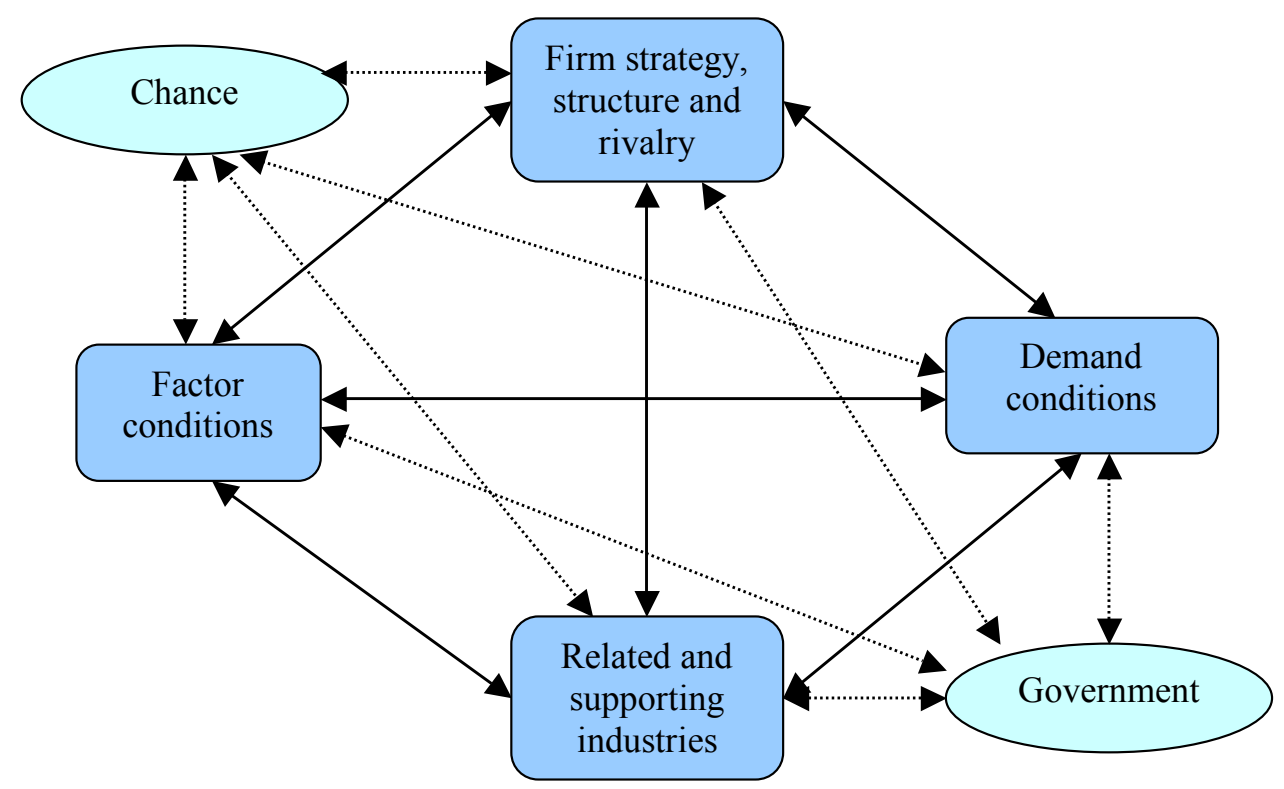

Fig. (1). The Porter's diamont of competitive forces [14].

Competitive advantage based on only one or two decisive factors may arise in sectors, which depend on natural resources, and in those with a low technological level. This type of advantage is usually unsustainable, as it changes rapidly and worldwide competitors can easily affect it. In order to achieve and maintain the competitive advantage in sectors and sectorial segments that are more advanced and knowledge-intensive it is usually necessary to have advantages in the whole diamond, since this circumstance allows a high rate of improvement and innovation. The advantage is maintained when its sources are increased and improved. In this sense, the conditions that facilitate dynamic advantages (faster innovation, pressure to improve, etc.) are more important than those that confer static advantages (costs of the factors, large domestic market, etc.). These considerations help to clarify the distinction between the existence of "comparative advantages", based on natural resources and cheap labour, and "competitive advantages", based on the diamond as a whole [25].

Porter's theory also allows a dynamic and strategic analysis, as it stresses the importance of the factors affecting competitiveness in the medium and long term. It considers that the sectors that advance due to the perfectioning of their competitive positions do so by obtaining competitive advantages of a superior level. It establishes four stages of competitive development that are brought about by factors, investment, innovation and wealth. The first three phases assume progressive improvement of the competitive advantages and they are usually linked to a rise in economic prosperity, while the fourth one is linked to relative inaction and, in time, decline.

Porter's cluster concept has been classified as "chaotic" [26], a "work in progress" [27] or excessively "flexible" [28]. Nevertheless, although its conceptual validity may be somewhat limited, it has been recognized as a theoretical instrument of general applicability which is apt to interpret the organization of quite different productive scenarios. Thus, though most cluster analyses have focused on activities based on learning and knowledge (telecommunications, information technology, electronics, etc.), this approach is valid for, and has also been applied to, productive sectors based on natural resources. Examples of the application of this theoretical framework to the competitiveness of clusters based on agricultural activity include the Dutch Flower Cluster [25] and the Mexican horticultural cluster.

\section{THE EMERGENCE: FACTOR ENDOWMENT AND PUBLIC INTERVENTION}

If we are to try to explain the process which allowed the irruption of intensive horticulture in Almería we must take into account a whole series of natural, institutional, social and technological factors which interacted in a complementary and accumulative fashion.

First of all, the natural conditions were decisive in the advent of this new economic activity. Almería, the easternmost province of Andalusia, is situated in the southeast of the Iberian Peninsula (Fig. 2). Along its $231 \mathrm{~km}$ coastline to the south lays the Mediterranean Sea. The physical environment of this province is quite unique in the European context [29], and some of its more specific features make it ideal for intensive horticulture (this is particularly true in the case of the Campo de Dalías, the focal point and largest area of this type of agriculture). Among these features we should highlight the suitable climatic conditions for the production of vegetables out of season, which give growers in this area comparative advantages over the rest of Spain and Europe as they can supply their produce at times of the year that are impossible for other producers. Despite little precipitation (150-200 $\mathrm{mm}$ per year), the high temperatures and long hours of sunlight constitute an important asset for the development of horticultural production. The average annual temperature is between $15^{\circ}$ and $20^{\circ} \mathrm{C}$, never falling below $18^{\circ} \mathrm{C}$ on the coast, where the winter months are extremely mild $\left(12-14^{\circ} \mathrm{C}\right)$ and the daily and annual temperature ranges are moderate due to the regulatory effect of the Mediterranean Sea, with little or no risk of frost. Some areas of Almería enjoy over 3,500 hours 

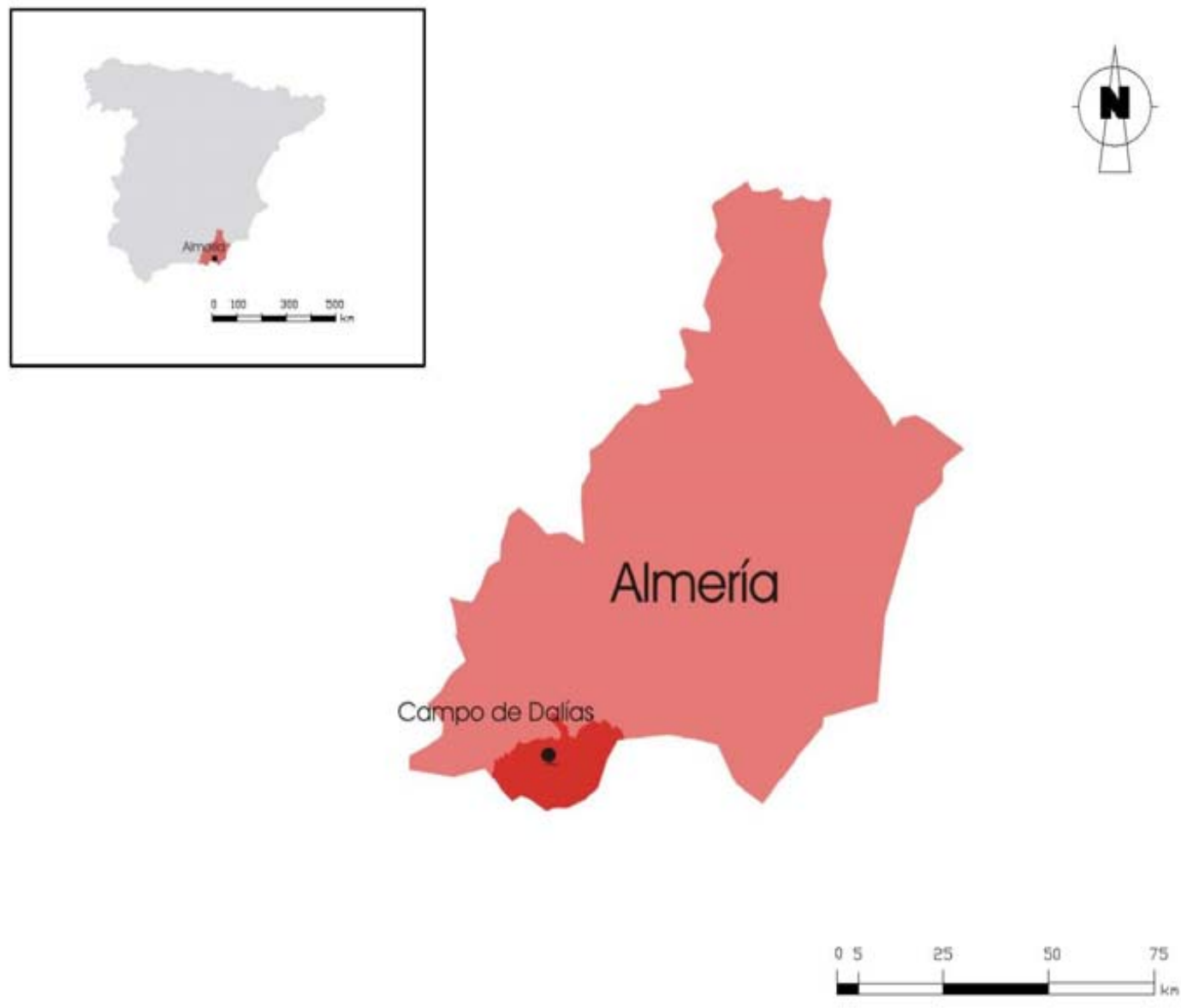

Fig. (2). Location of the area under study.

of sunlight per year, and the figure is between 3,200 and 3,500 in the Campo de Dalías. Moreover, Almería is a particularly windy province, and this climatic feature has been harnessed to control the climatic conditions inside the greenhouses, thus avoiding excessively high humidity and temperatures.

The relief of the province is highly varied but particularly mountainous, and most of the territory has slopes of over $15 \%$ (Fig. 3). Six principal mountain ranges run across the province from west to east (four of them are over 2,000 $\mathrm{m}$ in altitude). The Sierra de Gádor reaches an altitude of 2,242 m and is situated to the north of the vast plain known as Campo de Dalías. This location is another important asset, since the immense mountainous mass acts as an almost insurmountable barrier against storms and winds and helps to create a special microclimate [4]. Furthermore, although the low precipitation results in a shortage of surface water and a fluvial system consisting of river beds that remain dry during most of the year, the Campo de Dalías enjoys ample provisions of subterranean water (Fig. 4).

The mild winter temperatures, little temperature variation between day and night-time temperatures, high number of hours of sunlight, little humidity and frost, constant winds, flat surface and availability of underground water resources constitute the main environmental factors favouring the development of early horticultural crops in the Campo de Dalías. In addition, the geographical proximity of the European market is a positive factor in terms of transport costs and transit times.

However, to a great extent the activation of these natural resources took place thanks to suitable public intervention by the Ministry for Agriculture via the National Institute for Colonisation from the 1950's onwards. First and foremost, they allowed the underground water resources to be tapped by supplying the necessary technology in the form of mechanical wells and establishing the basic hydraulic infrastructure [31]. Secondly, the technicians of this organism introduced and spread the "enarenado" technique, which makes a two-fold contribution. On the one hand it allows the use of irrigation water of poor chemical quality and soils with a high level of salinity as those in Campo de Dalías; and on the other it makes a significant contribution to permitting early harvests. Thirdly, they assayed and promoted the construction of plastic greenhouses which reduce evotranspiration, improve the temperature regime and protect plants against the damaging effects of the wind. 


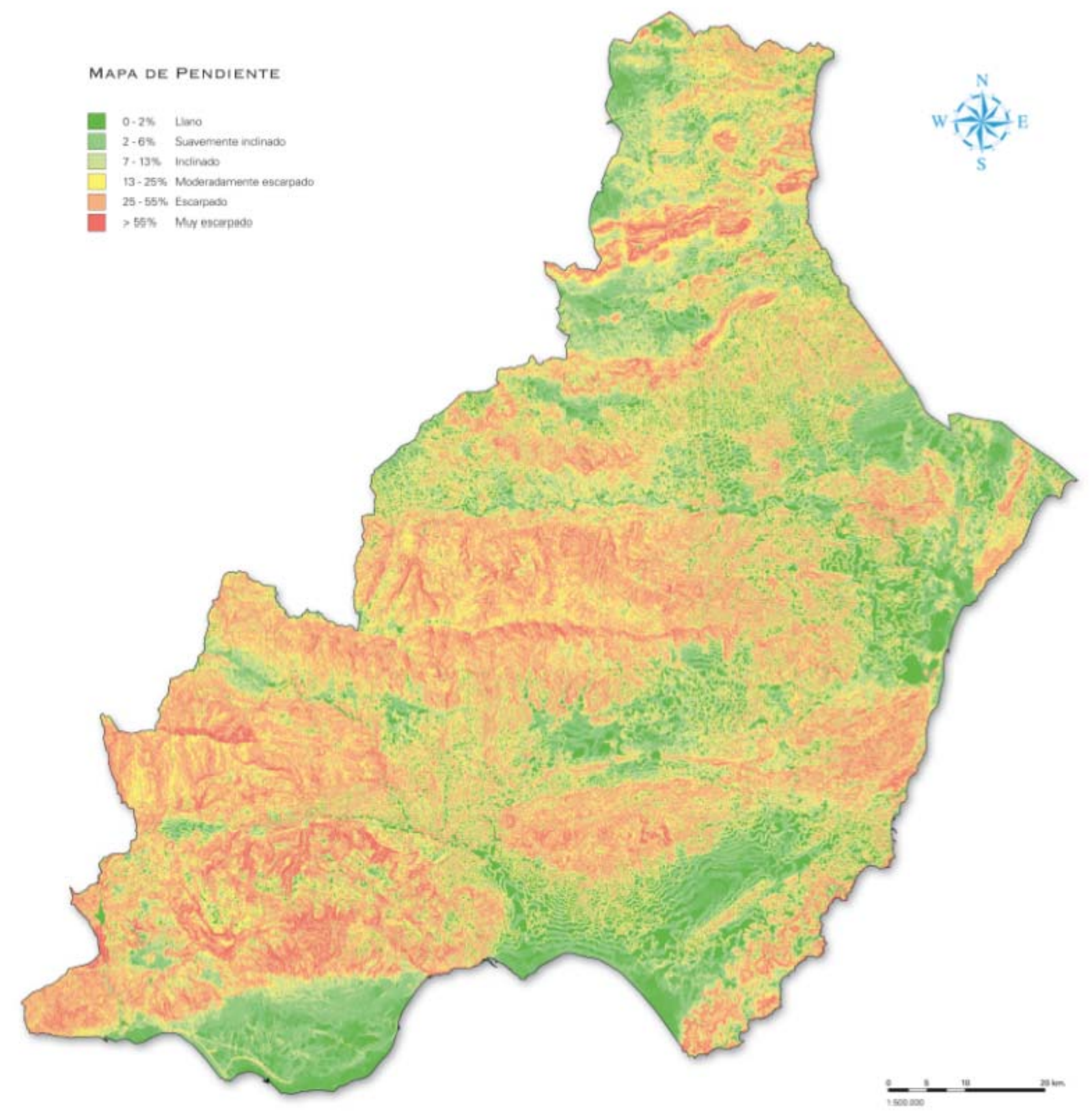

Fig. (3). Relief map of the province of Almería [30].

These improvements led to increases in productivity and earliness of the harvests [32].

Finally, the labour factor is the third major element to explain the rise in intensive horticulture in Almería. At the beginning of the 1950's the Campo de Dalías was targeted by the Plan General de Colonización (a Settlement Plan) with a view to exploiting what had hitherto been a vast expanse of uncultivated land used only by livestock farmers of limited profitability. The offer of colonization coincided with the crisis of traditional Mediterranean agriculture, and so many peasant families from the neighbouring mountains, attracted by the prospect of owning land and by the high profitability in comparison with traditional agriculture, took over the plots that had been transformed by the Institute. Plots of fewer than 3.5 hectares were shared out, and preference was given to married couples and those with most children, thus setting the basis for a model of family-run farms which has lasted to the present day. In the beginning all the family members took part in the agricultural tasks and the construction of the dwelling ("cortijo") adjacent to the greenhouse enabled them to work longer hours. In addition, these colonizers brought with them a secular hydraulic tradition and the experience of working with vines, and this 


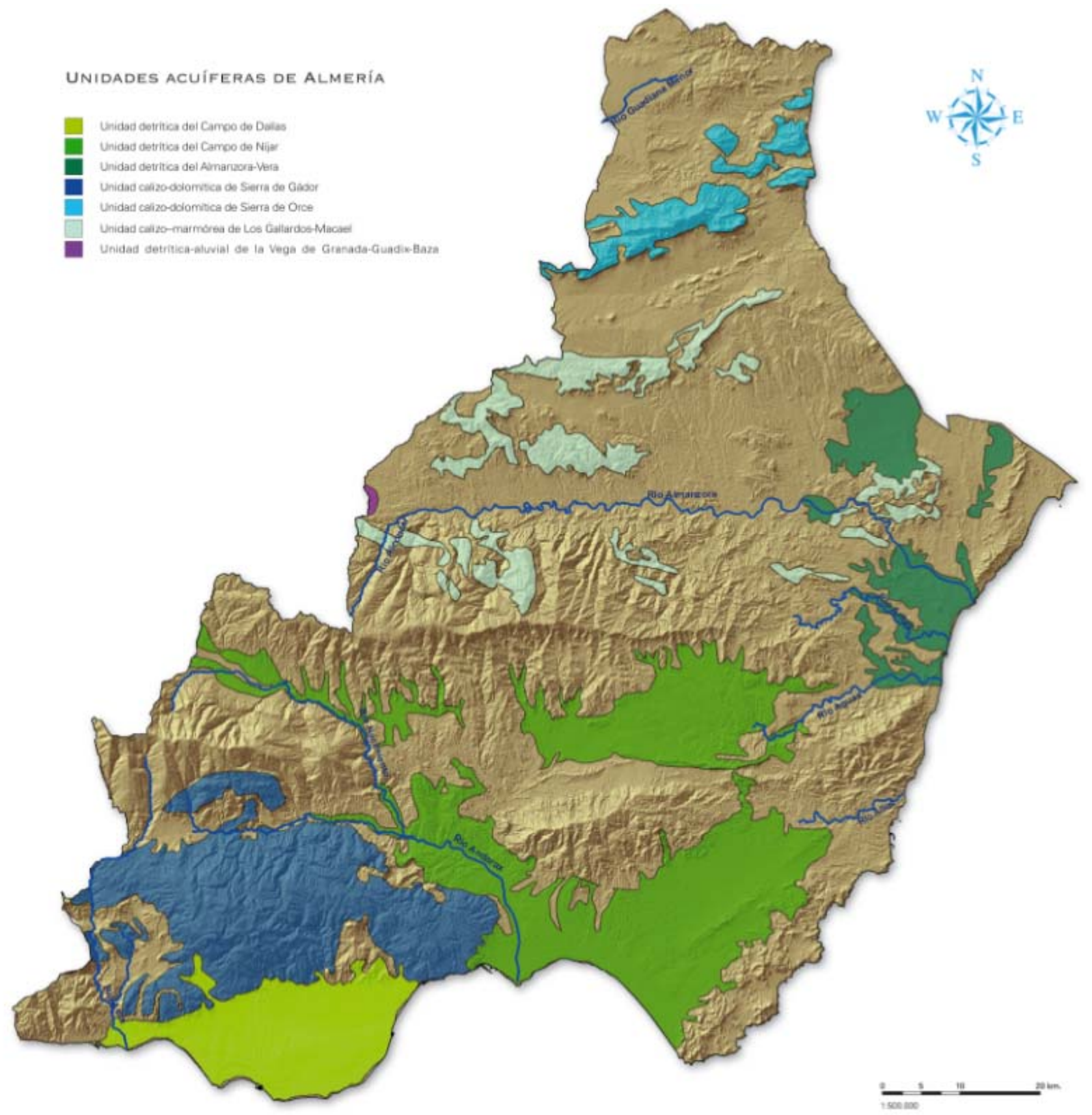

Fig. (4). Aquifers of the province of Almería [30].

allowed them to apply swiftly the technological innovations that were developed. In this way their entrepreneurial capacity together with their family work ethic constituted a major factor in the boom of this sector [33].

The Almería model of intensive agriculture was originally based on these pillars. Nevertheless, its continued growth has required permanent evolution of the systems of production, innovation and marketing, enabling it to attain both a high degree of development and a vast dimension.

\section{DEVELOPMENT: PRODUCTION, INNOVATION, MARKETING AND DIMENSION}

As regards production, there has been progressive substitution of labour for capital, while the basic structure of the farms has been maintained. Over time the average size of the concerns has grown, favouring the accumulation of capital, and this has occurred in part due to technological improvements in the greenhouses, which have allowed farmers to manage ever-greater surface areas (the average surface area of greenhouses has increased from 1 hectare in the mid-1980's to 2.5 hectares at present). Despite this trend, 
most concerns are still small-scale and predominantly family-run affairs, though paid labour has become increasingly common [33]. The change from phase characterized by workers coming from the family to a phase with a high percentage of wage earning employment has not been adequate. The poor management of this incorporation, with a growing number of immigrant workers, has produced difficulties and has become a challenge. To meet this challenge measures have been implemented to make the work more attractive (fixing salaries linked to production, mechanization of the most arduous tasks, etc.) and formulae have been sought to provide job stability and to facilitate specialization [3]. Furthermore, the different grower organizations are encouraging contracts in the country of origin of the immigrant workers in order to achieve better management and adaptation to the requirements of the sector.

Regarding innovation, there has been constant and ever greater introduction of improvements to respond to the needs and particular features of the area (drip irrigation, thermal plastic, soilless crops, and pollination by bees, industrial greenhouses, climate control, integrated pest and disease control, etc.). The constant incorporation of new technologies which are increasingly perfected and efficient has meant that there has been an increasing rate of technification in the management of greenhouse crops. Intensive horticulture now constitutes a technologically and institutionally complex and dynamic system which involves the use of great amounts of water, labour and different agrochemicals on semi-artificial soils, all under the protection of polyethylene coverings. The incorporation of innovations has been widespread and has led to substantial improvements in yield. Indeed, the average production per hectare has increased more than two-fold, rising from 25 tonnes in 1975 to over 65 in 2009 [3]. In addition to increased production, there has been an increase in quality and in the farming calendar, farmers now being able to obtain two or three harvests a year. As a result, the term "forced crops" has been coined. Over this period of time the province has become home to research and development centres, which have focused their attention on solving the problems facing the sector and on promoting the development of innovations [34]. There has been a growing degree of collaboration between these centres and the establishment of the Almería Innovation and Technology Park (PITA) will help to bring together institutions and research centres linked to the horticultural sector.

As regards marketing, the sector has built up its own structures which have allowed it to offer considerable volumes of supply, to be constantly present in the markets and to retain a major proportion of the added value generated in this phase. Over time the sector succeeded in connecting the marketing channels by means of an autochthonous model consisting of two modes which both complement and compete with one another: an initial phase of sale at origin by auction and a later phase of direct sales to consumer markets via the growers own marketing groups. This marketing model currently accounts for the practical totality of horticultural produce of Almería. In addition, the continuous improvement of autochthonous marketing channels, together with the possibility of selling the production on European Community markets from the 1990's onwards, allowed the swift, continuous incorporation of horticultural production for export $[35,36]$. In this way, foreign sales have gained increasing significance. They accounted for only $9 \%$ of total sales in 1980, but represented over $56 \%$ in 2009 [3].

The surface area of greenhouse horticultural production has risen spectacularly over the last few decades, rising from barely 3,000 hectares in 1975 to around 27,000 hectares in 2009. This makes Almería the first Spanish province in terms of greenhouse surface area, accounting for over half of the national total. It should also be pointed out that Spain is the leading country in terms of greenhouse area in the Mediterranean basin, ahead of Italy, Turkey, Morocco, France and Israel. We should also bear in mind that most of the greenhouse surface area in Almería is located in the Campo de Dalías, which is the prime example of intensive horticulture, accounting for over $70 \%$ of the provincial total. This area of approximately 37,000 hectares includes 16,000 hectares of greenhouses. This area constitutes, therefore, one of the greatest territorial transformations to have taken place in Europe in the last third of the $20^{\text {th }}$ century. This is made quite clear by the satellite images taken in 1974 (showing a typical agricultural rural area) and in 2004 (illustrating the spectacular increase in plastic greenhouses) (Fig. 5). The vast extension this sector covers allows it to take advantage of economies of scale and economies of agglomeration based on the largest concentration of plastic greenhouses in the world. However, the lack of territorial planning in this phase of growth gave rise to increasing negative environmental externalities (over-exploitation of aquifers, accumulation of residues, etc.), territorial congestion, deficit of public infrastructures and services and conflicts with other activities, in particular residential and tourist activities [37, 38]. From the early 1990's, an environmental management was launched, and at the present time many of these problems are being solved [6, 39, 40]. In addition, the greatest concentration of greenhouses in the world seems to have a positive impact on the struggle against climate change [41].

\section{MATURITY: THE AGROINDUSTRIAL CLUSTER}

From the late 1980's onwards an agroindustrial cluster began to emerge in Almería around the production and marketing of vegetables. Prior to that most of the inputs used by intensive horticulture came from other countries or Spanish provinces with greater horticultural tradition, although some local manufacturing and supply companies had begun to appear. In the 1990's a period of considerable growth commenced with the establishment of production and distribution centres in the province and the creation of autochthonous firms in the different sectors of auxiliary activities around horticultural production. In the services activities, local initiative has detected and undertaken most of the developments (handling and marketing, transport, IT services, agronomic counselling, financial assistance, etc.). Regarding industrial activities, there is a majority presence of local companies in some sectors (greenhouses, plastics, irrigation and fertirigation and packing), as well as increasing presence in some sectors, which supply technological inputs (agrochemicals, seeds, biological production and machinery) [42]. 


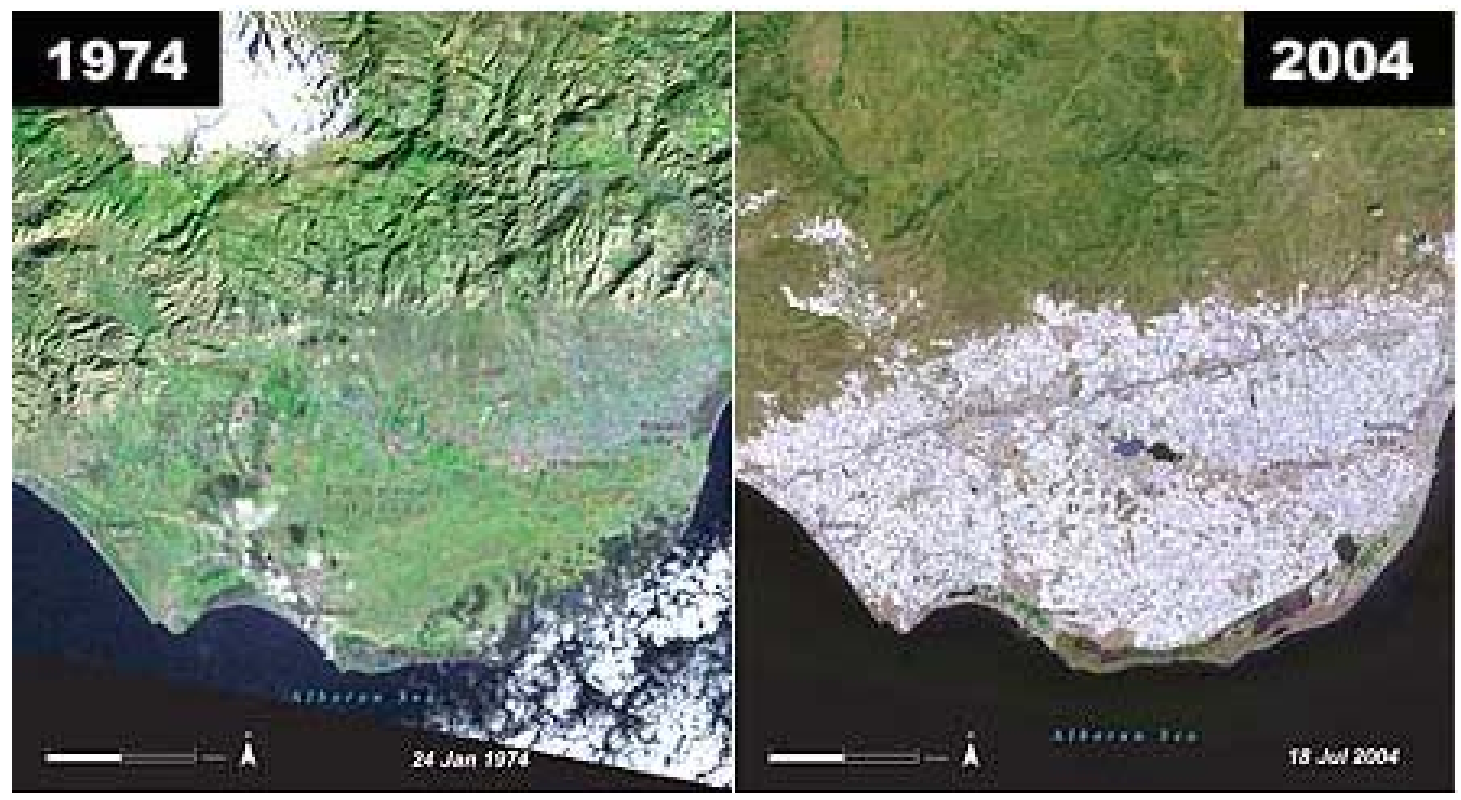

Fig. (5). Satellite images reflecting the development of intensive greenhouse horticulture in the Campo de Dalías (Almería) [2].

The extension and diversification of the set of industrial activities and services around the intensive horticulture has increased, giving rise to a complex network of economic relationships which define the present agroindustrial cluster in Almería (Fig. 6). A productive system has been established around greenhouse horticulture, which has the capacity to produce activity in its environment. On the one hand, it creates backward linkages since it is highly intensive in intermediate inputs (seeds, fertilizers, phytosanitary products, plastics, irrigation installations, etc.) and, on the other hand, forward linkages, generating activity related to the handling and marketing of horticultural production (containers and packaging, handling machinery, transport, etc.). In addition, there are several intensive agriculture research centres and professional associations, as well as a growing trend towards foreign markets, not only for horticultural production, but also for a considerable proportion of the auxiliary industries and services.

The continuing dynamics of this cluster are illustrated by the evolution in turnover, the number of firms, the employment generated and sales on international markets. There are over 500 firms supplying services and industrial inputs; their turnover is in excess of 6,000 million euros, well over 200 million of which are from foreign markets, and they directly employ almost 19,000 people [43].

Nevertheless, although these figures are impressive, the most relevant factor is the productive links that are established between the different sectors that make up the cluster, in such a way that the sum is much more than the total of the different parts. Thus, as well as the productive links of the auxiliary industries and services with the primary activities that justify their creation (production and marketing of vegetables), a network of commercial and cooperative relationships has been created which both strengthen and integrate the cluster. The creation of this cluster has permitted the sector to make a qualitative leap towards sources of competitive advantage of a higher order.

\section{ANALYSIS OF COMPETITIVENESS}

Studying the situation of Almería's horticultural sector in each of the determining factors of the competitive advantage following Porter's theoretical model proves very useful, as the knowledge of the state of the diamond provides valuable clues as to its productive potential and the conditioning factors of its future development [44].

\section{Conditions of the Factors}

Almería possesses excellent natural resources, which fulfil all the necessary agronomic conditions for optimal horticulture in plastic greenhouses. The availability of water resources may become a limiting factor, but steps are being taken to avoid this, introducing measures for economy of water in irrigation systems, increasing supply by means of desalination plants, reservoirs and recycling, and by studying the aquifers' capacity and evolution with a view to establishing a suitable framework for regulating demand. The geographical location is most appropriate since the proximity of the European markets allows not only savings in transport costs, but also enhancement of quality (due to prompt arrival at the markets of destination), as well as a rapid capacity of response in commercial terms.

The high degree of geographical concentration in the province, and more specifically in the Campo de Dalías constitutes a major asset as it enhances the mutual strengthening of each of the vertices of the diamond. Since competitors, customers and suppliers are also highly concentrated, efficiency, specialization, improvement and innovation are enhanced. In addition, there is a faster flow of information within the sector and a swifter spread of innovation.

The province possesses suitable infrastructure to allow overland access to the European market. A project is also under way to exploit sea transport, which may well become a major complementary alternative in the future. Access to financing is both easy and cheap thanks to the well- 


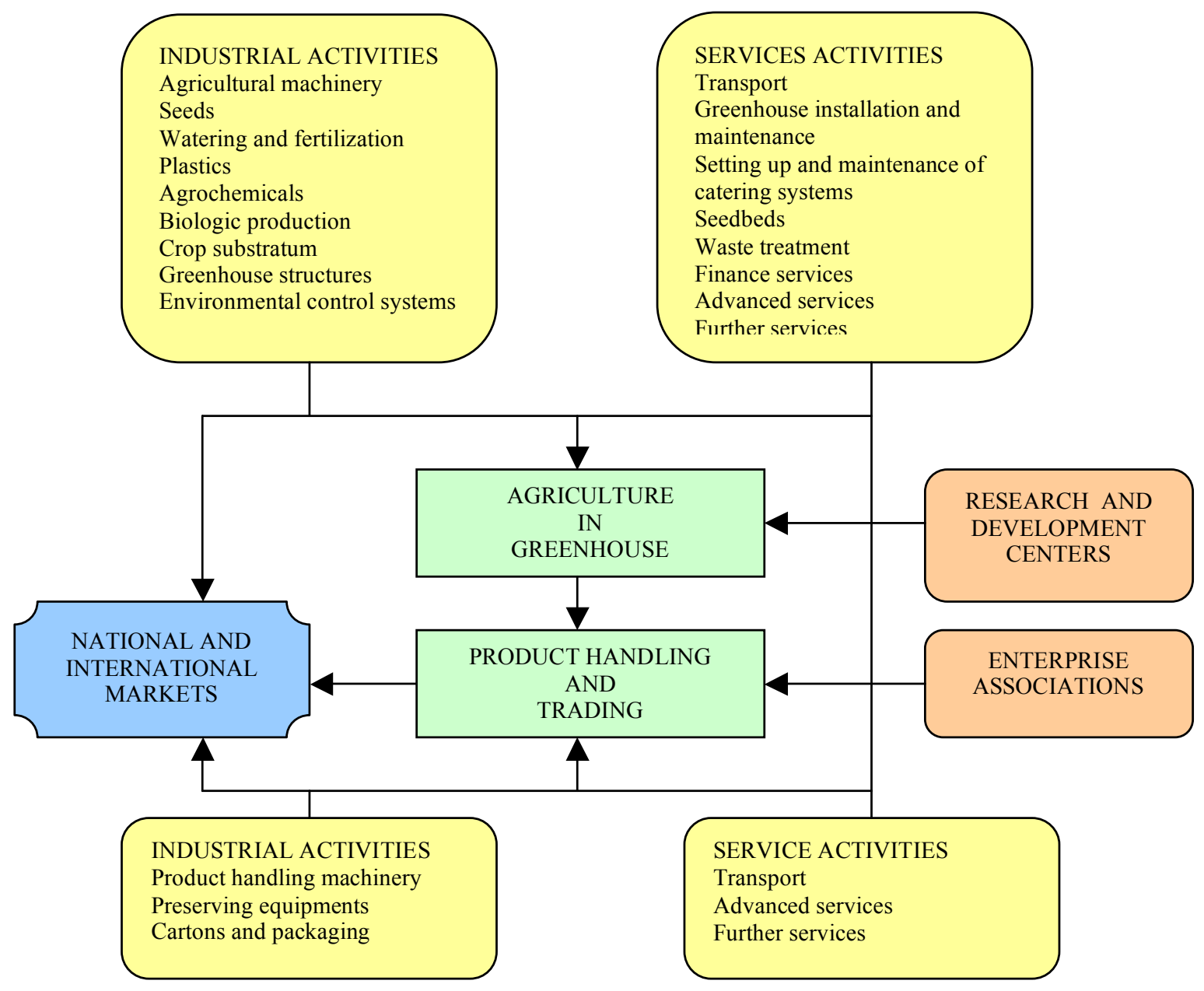

Fig. (6). Production links of the agroindustrial cluster of Almería.

developed capital markets. Those seeking financing have a wide range of financial institutions at their disposal that are willing to finance ventures and that are committed to the sector (the country's most important credit cooperative, Cajamar, had its origin in Almería and was directly involved in the emergence and expansion of the horticultural sector).

As far as the labour factor is concerned, there is a marked difference between unqualified and qualified labour. Regarding the former, although greenhouse work is still a family concern to a great extent, there has been ever-greater recourse to paid labour. In the last decade labour costs have been maintained thanks to the arrival of increasing numbers of immigrants who have kept salaries low and have been extremely flexible regarding conditions. Nevertheless, poor management of the incorporation of immigrant labour to this sector has given rise to certain difficulties whose solution now constitutes one of the sector's major challenges. In light of this, a series of measures is being prepared to make greenhouse work more attractive, to provide greater stability in the workplace and to facilitate specialization. At the same time there is increasing diffusion of innovations, which allow economy of labour, both in the greenhouse itself and in the handling centres. On the other hand, there has been ever-greater availability of qualified, specialized labour (agricultural engineers, marketing experts, advisers, industrial technicians, etc.) thanks to several prestigious training centres that guarantee a steady supply.
As regards knowledge resources, the trajectory of the sector has allowed it build up a considerable amount of know-how based on learning by doing and formal learning. In the province there are research and development centres that are focusing research towards solving the needs of the sector and there is increasingly close collaboration between these research centres and local firms. Those firms linked to supply sectors are also becoming actively involved in tasks of applied research. As the technological capacity of this sector has increased, local firms have augmented their investment in research. The results have been impressive, particularly in the technologies of processes which are adapted to the specific conditions of the sector in this province. The research centres are starting to exchange significant amounts of information with firms and to make known the results of their research. Moreover, the territorial concentration of the sector stimulates the exchange of knowledge and the diffusion of new technologies and innovations.

\section{Conditions of Demand}

The Spanish home market is well organized and demand is high. In addition, there is a very wide range of customers on the foreign market supplied by Almería. Almería responds to the demand of all the European countries (including the most demanding ones) as well as the USA and Canada (markets with stringent phytosanitary conditions). 
What is more, a major proportion of marketing firms work directly with the distribution chains (a very well-versed and demanding channel).

\section{Associated and Auxiliary Sectors}

In this regard, Almería is at a great advantage, as there are numerous major local suppliers of all sorts of components, machinery and specialized services. In addition to local suppliers, the world leaders of each subsector are also present. The horizontal and vertical depth of the cluster of associated and auxiliary activities is considerable, ranging from the elaboration of intermediate products and other inputs, to specialized machinery required by the sector and by the supporting services. The intense competition within the cluster, the great numbers of potential customers, the presence of others who have successfully set up their own businesses, previous experience in firms from the same cluster or from similar activities, together with the slight limits on the market all mean that there has been much incorporation. Thanks to the continuous formation of new firms, the cluster is gaining in depth and width, increasing its contribution to the development of the horticultural sector in Almería. They also help to create a climate of change and improvement, and they become allies and partners in the innovation process.

Horticultural exploitations and handling centres benefit from the presence of a well-developed group of local suppliers and producers of all types of important inputs, as in the same province they can find the best suppliers and a growing number of specialized personnel. This presence increases the efficiency of the purchase function as they are able to visit several suppliers in the same outing. It also reduces purchase risk, since they can use several suppliers simultaneously or change from one to another without difficulty. Costs and delays are reduced to a minimum in comparison with imported supplies form distant suppliers, and any repairs or problem solving also become easier when the supplier is close at hand. In addition, local supply is a limiting factor on opportunist behavior on the part of suppliers, who are less likely to impose excessively high prices or fail to produce when they make a commitment. Their relationship with customers is more transparent and long-lasting and any bad commercial behavior on their part would have an adverse effect on their reputation among firms in the sector. Communication is enhanced, the cost of adapting to new circumstances is reduced and it becomes easier to provide auxiliary services such as installation, elimination of defects, user training, problem solving and repairs. Moreover, the presence of many firms in each of the supply subsectors gives rise to a high degree of competition for the local market, and these firms must make a concerted effort to provide the best prices, services and products. At the same time, the suppliers benefit from the presence of so many customers who are both highly knowledgeable and demanding.

In the case of Almería the advantages derived from local supplies are multiplied by the fact that most customers and suppliers are located so closely together in the Campo de Dalías. This close proximity contributes to the interaction between them and encourages working relationships, strengthening both their positions and allowing a most efficient, almost vertical integration. Both sides of this relationship are benefiting from the short communication lines, the swift and on-going flow of information and from the permanent exchange of ideas and innovations. On the one hand, the Almería-based firms are influencing the technical efforts of their suppliers by explaining their needs or pointing out the shortcomings of the products on offer, and they act as a field test for the introduction of new products, helping to speed up the rate of innovation. On the other hand, suppliers can work with maximum efficiency thanks to the territorial concentration of their customers and the fact that their purchasers are both knowledgeable and demanding and so will push them to innovate, since in many subsectors the only way to attract new customers is by introducing improved products.

\section{Structure, Strategy and Rivalry of the Firms}

The scenario in Almería is favourable towards investment due to the stability of the sector and the facilities for the creation of new firms. As regards the aims of firms and individuals, as most producers are still family-run concerns there is a high degree of motivation to work and gain know-how. Therefore a great degree of personal commitment to the activity, highly competitive spirit and reduced aversion to taking risks are habitual traits in this province's horticultural sector. Furthermore, on the whole this activity enjoys social and political recognition due to its major contribution to the development of the province, and so there is a channelling of labour into the horticultural sector and the cluster of associated activities.

The existence of a great number of internal rivals and intense local competition constitute another of Almería's great advantages. Local competition is present in all fields, from production to marketing and on to the cluster of associated activities. Competition between local rivals has particularly strong motivating effects given the facility to draw constant comparisons and since local competitors tend to find themselves in similar circumstances, which encourages them to try to stand out in a creative way. This is one of the most determining factors in the stimulating effect on all of the vertices of the diamond. Moreover, the close geographical proximity multiplies the inside competition and provides a personal note to the intense rivalry (almost all the firms are family-owned and their owners live close to one another and know each other).

\section{Public Administration}

Among the most important and traditional functions of the State is the creation and enhancement of factors, whether they be human, technological, scientific or infrastructural resources. Bearing in mind that sectors obtain advantages not so much from the factors available to them but rather from the existence of institutional mechanisms that help them to improve the factors, Almería also appears well-prepared for suitable investment by the different entities of public administration in the fields of education, science, technology and infrastructure. These entities have also contributed to creating a suitable environment for firms to achieve competitive advantages.

Regarding the legislative power of the State and its influence on the competitiveness of the sector, we should 
take into account not only national policies but also international ones. Since 1986 Spain has been a member of the European Economic Community, and the Common Agricultural Policy and the Common Market Organization for Fruit and Vegetables represent important legislative frameworks in which the Almería sector has had to operate. Generally speaking, the strict national and European norms regarding product safety, phytosanitary practices or environmental protection have helped to build up and perfect Almería's competitive advantage, as they have put pressure on local firms to improve quality, perfect technology and contribute distinctive aspects in areas of great importance to customers. At the same time they have encouraged the creation of services firms or specialized manufacturers who help producers to comply with the norms.

\section{CONCLUSIONS}

Analysis of the process of change that Almería's intensive horticulture sector has undergone since the 1960's allows us to state that it has evolved from a model based on absolute competitive advantages at the outset to one based on systemic and dynamic competitive advantages. The sector grew up in the 1960's thanks to an initial advantage based fundamentally on a series of ideal territorial resources for cultivating vegetables in greenhouses which allowed it to produce at times of the year which were not possible in other European countries. However, in time a whole series of improvements has been implemented, helping to build up an agroindustrial cluster which has allowed the sector to pass beyond the initial competitive development phase, driven by factors to another phase stimulated by investment and innovation, generating another series of systemic and dynamic advantages.

From the analysis of competitiveness of Almería's horticultural sector following the analytical framework of Porter, it becomes clear that the sector is strong at all the vertices of the diamond. The intense inside competition, competitive local suppliers, the suitable environment for the creation of new firms, the high degree of geographical concentration, the high levels of motivation and commitment, the swift improvement of production factors and the efficient formal and informal mechanisms of connection between the members of the sector have created a strong scenario for innovation and improvement of competitiveness.

The competitiveness of Almería's horticultural sector is based on the presence of all the vertices of the diamond pulling together to constitute a system. The complex interactions between the determining factors within this system provide the firms with singular competitive advantages over their competitors, since the latter have to compete against a whole system, not individual firms. The organic nature of this system is the most difficult advantage to imitate, and therefore the most sustainable one that Almería's firms possess; the presence of the system constitutes a major barrier protecting the sector as it is difficult to imitate, and to attempt to do so would be very time-consuming. The system allows the whole sector to acquire its own impulse, activated by the broadening and mutual strengthening of the determining factors, advancing at a greater speed than can be achieved by rivals that are not part of a system. Competitive positioning founded on systems of activities such as the case of Almería are much more sustainable than those based on individual activities. Considered globally, Almería's horticultural sector presents the necessary conditions for progress and for great versatility to adapt to modifications in the markets or the sector. Nevertheless, there are several social, territorial and environmental problems which, if not resolved, may prove to limit its progress.

In short, Almería's horticultural sector has been able to approach suitably a reconversion process of the competitive advantages by taking a decisive step towards a much more advanced and, therefore, more sustainable stage of development. Its competitiveness is now based not only on the availability of privileged territorial resources, but also increasingly on its endowment with advanced factors (specialized personnel, contextual knowledge, research and development structures, training centres, etc.), the accumulation of experience, technological and productive innovation, a favourable institutional framework and the constitution of an agroindustrial cluster.

\section{ACKNOWLEDGEMENTS}

This research was partially funded by Spanish MCINN and FEDER aid ECO2008-02258.

\section{REFERENCES}

[1] Latorre JG, Picon AS, Latorre JG. The man-made desert. Effects of economic and demographic growth on the ecosystems of arid southeastern Spain. Environ Hist 2001; 6(1): 75-94.

[2] United Nations Environment Programme (UNEP). One planet, many people: atlas of our changing environment. Nairobi: UNEP 2005.

[3] Fundación Cajamar. Análisis de la campaña hortícola de Almería. Almería: Fundación Cajamar 2009. Available from: http://www.fundacioncajamar.es

[4] Tout D. The horticulture industry of Almería province Spain. Geogr J 1990; 156(3): 304-12.

[5] Mota JF, Peñas J, Castro H, Cabello J. Agricultural development $v s$ Biodiversity conservation: the Mediterranean semiarid vegetation in El Ejido (Almería, southeastern Spain). Biodivers Conserv 1996; 5(12): 1597-617.

[6] Downward SR, Taylor R. An assessment of Spain's Programa AGUA and its implications for sustainable water management in the province of Almería, southeast Spain. Environ Manage 2007; 82(2): 277-89.

[7] INE. Instituto Nacional de Estadística: Spain 2009. Available from: http://www.ine.es

[8] Vázquez-Barquero A. Surgimiento y transformación de clusters y milieus en los procesos de desarrollo. Rev Cult Econ 2007; 25(69): 38-57.

[9] Vázquez-Barquero A. Endogenous development. London-New York: Routledge 2002.

[10] Vázquez-Barquero A. Desarrollo endógeno. Teorías y políticas de desarrollo territorial. Investig Region 2007; 11: 183-210.

[11] Becattini G. Dal settore industriale al distretto industriale: alcune considerazioni sull'unita d indagine dell'economia industriale. Riv Econ Polit Indus 1979; 1: 7-21.

[12] Piore M, Sabel C. The second industrial divide: the possibilities for prosperity. New York: Basic Books 1984.

[13] Scott AJ. New industrial spaces: flexible production organization and regional development in North America and Western Europe. London: Pion 1988.

[14] Porter ME. The competitive advantage of nations. New York: The Free Press 1990.

[15] Cooke P. Knowledge economies. Clusters, learning and cooperative advantage. London-New York: Routledge 2002.

[16] Krugman P. Geography and trade. Cambridge: MIT Press 1990.

[17] Fujita M, Krugman P, Venables A. The spatial economy: cities, regions and internationaltrade. Cambridge: MIT Press 2000. 
[18] Aydalot P. Milieux innovateurs en Europe. Paris: Gremi 1986.

[19] Maillat D. Territorial dynamic, innovative milieus and regional policy. Entrepreneurship Reg Dev 1995; 7: 157-65.

[20] Granovetter M. Economic action and social structure: the problem of embeddedness. Am J Sociol 1985; 91: 481-510.

[21] North D. Institutions, institutional change and economic performance. New York: Cambridge University Press 1990.

[22] Porter ME. Cluster and the new economics of competition. Harv Bus Rev 1998; 76: 77-90.

[23] Porter ME. On Competition. Boston: Harvard Business School Press 1998.

[24] Bergman EM, Feser EJ. Industrial and regional clusters: concepts and comparative application. Regional Research Institute: West Virginia University 1999.

[25] Tavoletti E, Te Velde R. Cutting Porter`s last diamond: competitive and comparative (dis)advantages in the dutch flower cluster. Trans Stud Rev 2008; 15(2): 303-19.

[26] Martin R, Sunley P. Deconstructing clusters: chaotic concept or policy panacea? J Econ Geogr 2003; 3: 5-35.

[27] Benneworth P, Henry N. Where is the value-added in the cluster approach? Hermeneutic theorizing, economic geography and clusters as a multi-perspectival approach. Urban Stud 2004; 41(5/6): 1011-24.

[28] Belussi F. In search of a useful theory of spatial clustering: agglomeration $v s$ Active clustering. In: Cooke N, Martin RL, Asheim B, Eds. Cluster and regional development: critical reflections and explorations. London-New York: Routledge 2006; pp. 69-89.

[29] García-Latorre J, García-Latorre J, Sánchez-Picón A. Dealing with aridity: socio-economic structures and environmental changes in an arid Mediterranean region. Land Use Policy 2001; 18: 53-64.

[30] García A, Dir. Atlas geográfico de la provincia de Almería. Almería: Instituto de Estudios Almerienses 2009.

[31] Sánchez A. Los regadíos de la Andalucía árida (siglos XIX y XX). Expansión, bloqueo y transformación. Áreas 1997; 17: 109-28.

[32] Galdeano E, De Pablo J. La agricultura intensiva en el sureste español: análisis de los determinantes de su desarrollo. Economistas 1999; 81: 91-103.
[33] Aznar JA, Sánchez A. Inmigración en tierra de emigración: el caso de Almería. Economistas 2000; 86: 97-115.

[34] Pallarés-Barberá M. Enterprise embeddedness and industrial innovation in Spain: and overview. In: Taylor M, Leonard S, Eds. Embeddedness enterprise and social capital. Aldershot: Ashgate Publications 2002; pp. 113-25.

[35] Martínez-Paz J, Martínez-Carrasco F, Dios-Palomares R. Analysis of the evolution of protected horticulture in Almeria area: cycles, structure and growth. Acta Horticulture 2001; 559: 713-8.

[36] Pérez-Mesa JC. Should Almería (Spain) have to worried, thinking that their tomato export is currently affected by international competition? Agric Econ Rev 2007; 8(2): 42-54.

[37] Pulido-Bosch A, Pulido-Leboeuf P, Molina-Sánchez L, Vallejos A, Martin-Rosales W. Intensive agriculture, wetlands, quarries and water management. A case study (Campo de Dalías, SE Spain). Environ Geol 2000; 40(1-2): 163-8.

[38] Gómez D. La horticultura en Almería. Bases para un Plan de Ordenación Territorial y Gestión Medioambiental. Almería: Cajamar 2003

[39] Ferraro FJ, Dir. El sistema productivo almeriense y los condicionamientos hidrológicos. Madrid: Civitas 2000.

[40] Galdeano-Gómez E, Céspedes-Lorente J, Martínez-del-Río J. Environmental performance and spillover effects on productivity: evidence from horticultural firms. J Environ Manage 2008; 88: 1552-61.

[41] Campra P, Garcia M, Canton Y, Palacios-Orueta A. Surface temperature cooling trends and negative radiative forcing due to land use change toward greenhouse farming in southeastern Spain. J Geophys Res Atmos 2008; 113: D18109.

[42] Aznar-Sánchez JA, Sánchez-Picón A. Innovación y distrito en torno a un "milagro": la configuración del sistema productivo local de la agricultura intensiva de Almería. Rev Hist Indus 2010; 42. 157-93.

[43] Ferraro FJ, Aznar JA. El distrito agroindustrial de Almería: un caso atípico. Med Econ 2008; 13: 353-82.

[44] Aznar JA. La competencia entre la horticultura intensiva de Marruecos y España. Navarra: Thomson-Civitas 2006.

(C) Aznar-Sánchez and Galdeano-Gómez; Licensee Bentham Open.

This is an open access article licensed under the terms of the Creative Commons Attribution Non-Commercial License (http://creativecommons.org/licenses/bync/3.0/) which permits unrestricted, non-commercial use, distribution and reproduction in any medium, provided the work is properly cited. 